\title{
Pseudomonas anatoliensis sp. nov and Pseudomonas iridis sp. nov. isolated from fish
}

\author{
Muhammed Duman ${ }^{\mathrm{a}}$, Magdalena Mulet ${ }^{\mathrm{b}}$, Soner Altun ${ }^{\mathrm{a}}$, Izzet Burcin Saticioglu ${ }^{\mathrm{c}}$, Margarita Gomila ${ }^{\mathrm{b}}$, \\ Jorge Lalucat $^{\mathrm{b}, \mathrm{d}}$, Elena García-Valdés ${ }^{\mathrm{b}, \mathrm{d}, *}$ \\ a Department of Aquatic Animal Diseases, Faculty of Veterinary Medicine, Bursa Uludag University, 16059 Bursa, Turkey \\ ${ }^{\mathrm{b}}$ Microbiologia, Departament de Biologia, Edifici Guillem Colom, Universitat de les Illes Balears, Campus UIB, 07122 Palma de Mallorca, Spain \\ ${ }^{\mathrm{c}}$ Department of Aquatic Animal Diseases, Faculty of Veterinary Medicine, Erciyes University, 38280 Kayseri, Turkey \\ ${ }^{\mathrm{d}}$ Institut Mediterrani d'Estudis Avançats (IMEDEA, CSIC-UIB), Campus UIB, 07122 Palma de Mallorca, Spain
}

\section{A R T I C L E I N F O}

\section{Article history:}

Received 29 September 2020

Revised 5 March 2021

Accepted 9 March 2021

\section{Keywords:}

Pseudomonas

Rainbow trout

Oncorhynchus mykiss

Aquaculture

\begin{abstract}
A B S T R A C T
In a study carried out between 2013 and 2018 in fish farms in Turkey, several putative novel species were isolated. The $16 \mathrm{~S}$ rRNA nucleotide sequences of fourteen strains of Gram-negative rods, which were isolated from asymptomatic and symptomatic rainbow trouts (Onchorhynchus mykiss), placed them under the genus Pseudomonas. The similarity values of the concatenated nucleotide sequences of the rpoD, $r p o B$, gyrB and 16S rRNA genes clustered these isolates into the $P$. fluorescens phylogenetic group of species and into the Pseudomonas koreensis subgroup, close to Pseudomonas helmanticensis and Pseudomonas baetica. An isolate of a totally different origin, strain CCUG 67011, clustered with these isolates. Phenotypic characterization, together with the chemotaxonomic data, whole-cell MALDI-TOF MS and fatty acids methyl esters analyses were performed. The DNA G $+\mathrm{C}$ content was $58.7 \mathrm{~mol} \%$ for isolate $\mathrm{P}^{\mathrm{T}}$ and $58.8 \mathrm{~mol} \%$ for isolate $\mathrm{P} 42^{\mathrm{T}}$. The phylogenomic analysis and whole genome nucleotide sequences of four of these isolates confirmed that the isolates P9 ${ }^{\mathrm{T}}, \mathrm{P} 25$ and $\mathrm{P} 141$, represent a novel species for which the name Pseudomonas anatoliensis sp. nov. is proposed, with $\mathrm{Pg}^{\mathrm{T}}$ as the type strain $\left(=\right.$ CCUG $74755^{\mathrm{T}}=\mathrm{CECT}$ $3172^{\mathrm{T}}$ ). The isolates P1, P2, P10, P27, P30, P24a, P42 ${ }^{\mathrm{T}}, \mathrm{P} 117, \mathrm{P} 139, \mathrm{P} 152$ and CCUG 67011 represent another novel sècies, for which the name Pseudomonas iridis sp. nov. is proposed, with $\mathrm{P}^{\mathrm{T}} 2^{\mathrm{T}}$ as the type strain $\left(=\right.$ CCUG $74870^{\mathrm{T}}=$ CECT $\left.3174^{\mathrm{T}}\right)$.
\end{abstract}

(c) 2021 Elsevier GmbH. All rights reserved.

\section{Introduction}

In a surveillance study, which focused on Aeromonas, Flavobacterium and Pseudomonas species carried out in farm fisheries in Turkey, between 2013 and 2018, several putative novel species were isolated and characterized by a polyphasic approach [7]. Of these species, one was first described in 2020 as Pseudomonas sivasensis and comprised strains isolated from cultured fish species, but also from human specimens [6]. Another species described in the same study, Pseudomonas haemolytica was reported for the first time in this habitat [12]. Furthermore, other Pseudomonas species recently isolated from freshwater salmonids, have been reported as fish pathogens [22]. Farm fisheries may serve as a reservoir of potentially pathogenic Pseudomonas species and should be

\footnotetext{
* Corresponding author at: Microbiologia, Departament de Biologia, Edifici Guillem Colom, Crta. de Valldemossa km 7, 5 Universitat de les Illes Balears, Campus UIB, 07122 Palma de Mallorca, Spain.

E-mail address: elena.garciavaldes@uib.es (E. García-Valdés).
}

considered as posing a potential risk for transmission to humans. Therefore, the study and implementation of surveillance programs, and the identification of the causal agents are essential to both avoiding the spread of bacteria to different environments and sustaining the application of the One Health paradigm.

Ninety strains isolated from samples taken in the aquaculture settings from water, fish, eggs, or milt in the spawning period, and also from alevins, were identified as Pseudomonas species. Sixty-eight percent of the 90 strains were assigned to known Pseudomonas species and 32\% corresponded to putative novel Pseudomonas species. This study presents a polyphasic taxonomic characterization of a group of strains of two putative novel species not yet described before, but isolated in a surveillance program. The bacterial isolates were recovered from symptomatic and asymptomatic rainbow trouts farmed in Central Anatolia (Kayseri and Sivas provinces) and the Aegean region (Mugla province) between 2013 and 2018. A total of 14 Pseudomonas strains were considered as representatives of two putative novel species based on 16S rRNA sequence similarity and multi-locus sequence 
analysis (MLSA) of the gyrB, $r p o B$ and $r p o D$ genes. A strain of a totally different origin, strain CCUG 6701, isolated from a cystic fibrosis patient in Sweden [19] was phylogenetically closerelated and thus included in the present study. The delineation of the novel species was based on the biochemical characterization of all isolates by substrate utilization tests (API 20 NE, BIOLOG GN III) chemotaxonomic characterization (MALDI-TOFF MS protein and fatty acids profiles) and the whole genome nucleotide sequencing of selected strains.

\section{Materials and methods}

\section{Bacterial isolation}

Fourteen strains were isolated from rainbow trouts grown in fish farms located in the Central Anatolia region (10 strains from Kayseri province, 2 from Sivas province) and the Aegean region (2 strains from Mugla province), during the period from 2013 to 2018. Data, location, GPS coordinates, and the weight of the fish are shown in Table S1. The samples were aseptically collected from the skin of fish alevins with sterile swab sticks and plated on tryptic soy agar (Merck, 105458 TSA) and blood agar (BA; with 5\% sheep blood). The plates were incubated at $28^{\circ} \mathrm{C}$. Sampling was carried out in accordance with the guidelines for the diagnosis of fish diseases and in compliance with international guidelines for animal welfare [23] as previously reported [6]. The strain CCUG 67011 , was isolated from the sputum of a cystic fibrosis patient in Gothenburg (Sweden) [19].

\section{Morphological, biochemical and physiological tests}

The strains were routinely cultured in Luria broth medium (LB, Luria-Bertani, Difco) at $28^{\circ} \mathrm{C}$. Biochemical tests were performed using API 20 NE strips (bioMérieux, Marcy l'Etoile, France) and Bio$\log$ GEN III MicroPlates (Biolog, Hayward, CA) for the phenotypic characterization of the strains, in line with the manufacturer's recommendations. Different growth temperatures $(4,10,25,30,37$ and $42{ }^{\circ} \mathrm{C}$ ) and $\mathrm{pH}$ levels (4-11) were tested in LB medium. Growth in the presence of $\mathrm{NaCl}(0-10 \% \mathrm{w} / \mathrm{v})$ was tested in $\mathrm{NB}$ medium (Nutrient Broth, Difco). The fluorescence test was performed in King B medium as previously described $[6,16]$. Pyocyanin production was tested in King A medium (Himedia, M1543). The bacteria were also tested for haemolytic activity on blood agar (supplemented with $5 \%$ sheep blood) at $28{ }^{\circ} \mathrm{C}$. Cell size, morphology and flagella insertion were determined by the transmission electron microscopic observation of cells in the exponential growth phase in LB medium. A Hitachi model $\mathrm{H} 600$ electron microscope was used at $75 \mathrm{kV}$. The samples were negatively stained with phosphotungstic acid (1\%, pH 7.0) as previously described [14].

\section{Chemotaxonomic analysis}

Whole-cell fatty acid methyl ester (FAME) analyses were performed at the Spanish Type Culture Collection, CECT, Valencia, Spain (http://cect.org/identificaciones) by gas chromatography. For this purpose, an Agilent 6850 unit equipped with the MIDI Microbial Identification System using the RTSBA6 method and the Microbial Identification Sherlock software package version 6.1 were used. The selected method was applied as previously described [6]. The main protein profiles of the 14 strains and their close-related species type strains were obtained by the matrixassisted laser desorption/ionization time-of-flight mass spectrometry (MALDI-TOF MS) of whole cells. Data were obtained by the Scientific-Technical Services of the University of Balearic Islands (Spain) and were analyed as previously described [28].

\section{DNA extraction, PCR amplification and DNA sequencing conditions}

The DNA extraction method, and PCR amplification and DNA sequencing conditions applied in this study have been previously reported $[6,20]$. The genes that were amplified for phylogenetic analysis included 16S rRNA (1350 nt), gyrB, (RNA gyrase subunit B, $802 \mathrm{nt}$ ), rpoB (RNA polymerase beta subunit, $916 \mathrm{nt}$ ) and rpoD (RNA polymerase subunit D, $689 \mathrm{nt}$ ).

\section{Phylogenetic analysis}

An individual phylogenetic 16S rRNA tree was constructed with the sequences of the 14 isolates recovered in this study, together with the species type strains of the P. koreensis subgroup (SG), and $P$. jesssenii SG and with the representative type strains of the closest subgroups, namely, P. mandelii, P. fluorescens, P. gessardii, $P$. chlororaphis and $P$. corrugata. Distance matrices were generated by Jukes and Cantor method (JC) [13], and the tree was reconstructed with neighbor-joining (NJ) [27]. Trees were also constructed by Maximum likelihood (ML) [9] and Maximum Parsimony (MP) [21] methods as implemented in the MEGA package [29]. The multilocus sequence analysis (MLSA) tree was constructed by concatenating a total of 3757 nucleotides corresponding to partial sequences of four housekeeping genes (16S rRNA, rpoD, gyrB, rpoB), with the same algorithms (JC-NJ, ML, MP).

Multilocus sequence analysis (MLSA) based on 79 genes was performed on the autoMLST web server as described by Alanjary and collaborators [1]. Briefly, the uploaded genome sequences were analyzed together with their closest relatives detected by MASH ANI in the server database. The best single copy ubiquitous housekeeping genes were selected by the program and a maximum of 100 nucleotide sequences were concatenated and aligned. Phylogenetic distance calculations and tree building by maximum likelihood were performed on the autoMLST web server [1].

The core genome of $P$. anatoliensis and $P$. iridis strains was also calculated in the web server M1CROB1AL1Z3R [3]. Briefly, the putative open reading frames (ORFs) of each genome was extracted using Prodigal and a homology search in which each ORF was queried against the ORFs of the other genomes by using tBlastX. Orthologous groups were defined using default parameters: maximal evalue cutoff: 0.01 ; identity minimal percent cutoff: $80.0 \%$; minimal percentage for core: $100.0 \%$. Additionally, a maximum-likelihood phylogenetic tree was reconstructed based on the concatenated protein sequences of all core genes and using the genome of $P$. baetica type strain as outgroup. A UPGMA dendrogram was also constructed based on the ORFs shared by each pair of strains. The presence or absence in each genome of all orthologous genes found was coded as 1 and 0 and similarities were calculated using the Dice coefficient in the PAST program [11].

\section{Genome sequencing and analysis}

DNA was extracted from the strains $\mathrm{P9}^{\mathrm{T}}, \mathrm{P} 42^{\mathrm{T}}, \mathrm{P} 141$ and CCUG67011 with a QIAamp DNA Mini Kit according to the manufacturer's instructions (Qiagen, Hilden-Germany). The amount and purity of DNA in each sample were measured at wavelengths of $260 \mathrm{~nm}$ and 260/280 $\mathrm{nm}$ using a spectrophotometer (Multiscan Go, Thermo, USA). The sequencing library was prepared using the Nextera XT DNA Library Preparation Kit, and sequencing was performed on the Illumina NovaSeq 6000 platform using the 2x250-bp paired-end (PE) sequencing mode with a 1000-cycle MiSeq reagent kit. The reads with low-quality scores $(<20)$ or poly-Ns and adaptor contamination were trimmed using BBDuk implemented in Geneious Prime. High-quality reads of the genomes were assembled into contigs by de novo assembly using the SPAdes assembler 
3.13.0. Genomes were annotated using the Rast tool kit available in the Pathosystems Resource Integration Center (PATRIC) database (PATRIC 3.6.3), as part of the online all-bacteria Bioinformatics Resource Center. In addition, the annotated protein-encoding sequences were identified using the NCBI Prokaryotic Genome Automatic Annotation Pipeline (PGAP) [31]. Analyses were performed for GC content and genome size. The draft genome sequences were submitted to GenBank.

The genome relatedness of the strains $\mathrm{P9}^{\mathrm{T}}$ and CCUG 67011 to the whole-genome shotgun sequences of all species type strains in the $P$. koreensis phylogenetic subgroup available in public databases was determined based on the tetranucleotide frequency correlation coefficients (TETRA), average nucleotide identity (ANI) determined with the BLASTN algorithm (ANIb), and the results of analysis with the MUMMER ultrarapid alignment tool (ANIm). ANIb and ANIm were calculated using the JSpecies software tool available on the webpage http://jspecies.ribohost.com/jspeciesws/ [25]. Additionally, digital DNA-DNA hybridization between the selected strains was performed by the genome-to-genome distance (GGDC) method. GGDC was calculated using a web service (http:// ggdc.dsmz.de) [17] and the recommended BLAST method. The presented GGDC results are based on the recommended formula 2. The type strain genomes server pipeline (TYGGS, https://tygs. dsmz.de/) was used to compare the genomes of the strains $\mathrm{Pg}^{\mathrm{T}}$, $\mathrm{P} 42^{\mathrm{T}}, \mathrm{P} 141$, and CCUG67011 with the genomes of the type strains deposited in the DSMZ data base $[8,18]$.

All genomes were annotated with the PROKKA software tool for comparison purposes [30]. The protein amino acid sequences obtained were compared using the GET_HOMOLOGUES software [5], using the criterion of $70 \%$ similarity over $50 \%$ of coverage alignment. A functional analysis of the protein-encoding genes was also performed using the Kyoto Encyclopedia of Genes and Genomes (KEGG) database (https://www.genome.jp/kegg/)

\section{Results and discussion}

Isolation

Ten strains were isolated from asymptomatic trouts in the Kayseri city in different years. One strain, P117, was isolated from symptomatic fish displaying loss of appetite, anaemia, and dorsal fin erosion with no accompanying microbiota. Two isolates, P139 and P141, were associated to dead fish with accompanying flora (Flavobacterium sp.) (Table S1). The strain CCUG 67011 was isolated from a human specimen.

\section{Phylogenetic analysis}

The 16S rRNA sequences were identical in all 14 isolated strains and the phylogenetic analysis clustered them into the $P$. koreensis SG (Fig. 1), with similarity percentages of $99.3 \%$ to the type strain of $P$. baetica, and $99.4 \%$ with the type strain of $P$. helmanticensis, (Table S2). To improve the accuracy of the identification at species level, the 4-genes concatenated nucleotide sequences (MLSA) were compared to the $P$. koreensis SG type strains as shown in the dendrogram of Fig. 2. The corresponding matrix values are given in Table S2. The intraspecies similarity values ranged from 99.9 to $100 \%$ among the 3 strains: $9^{\mathrm{T}}, \mathrm{P} 25$ and $\mathrm{P} 141$ strains and from 99.2\% to $100 \%$ among the strains $\mathrm{P} 42^{\mathrm{T}}, \mathrm{P} 1, \mathrm{P} 2, \mathrm{P} 10 . \mathrm{P} 24 \mathrm{a} . \mathrm{P} 27$, P30, P117, P139, P152 and CCUG67011. The highest species type strain similarity values were determined as $95.5 \%$ and $95.2 \%$ for $P$. baetica with the $\mathrm{P}^{\mathrm{T}}$ cluster of strains with the $\mathrm{P} 42^{\mathrm{T}}$ cluster of strains, respectively (Table S2). The accepted MLSA species cutoff value for species differentiation is $97 \%[13,18]$. The concatenated 81-genes sequences (obtained with the autoMLST method) were also analyzed with the same strains, such that the same two clusters were observed as shown in Fig. 3 and all branches in the tree were supported by high bootstrap values. The results obtained in the present study suggested that these strains could belong to a two novel species in the genus Pseudomonas.

\section{Phenotypic characteristics}

The 14 strains were motile Gram negative-stained rods. The colonies were round, flat, opaque and beige colored, with regular and translucent margins and reached an approximate diameter of 3-6 $\mathrm{mm}$ after growth for 2 days at $30^{\circ} \mathrm{C}$ on LB plates. Electron microscopic examination revealed the presence of one monopolar inserted flagellum in the strains $\mathrm{P}^{\mathrm{T}}$ and $\mathrm{P}^{4} 2^{\mathrm{T}}$ as shown in Tables $2 \mathrm{~A}$ and $\mathrm{B}$ and Fig. S1.

The phenotypic characteristics that differentiated the 14 strains from their closest phylogenetic neighbours are given in Table 1. The complete list of phenotypic characteristics is given in Table 2 and Table S3. The proposals of new species are supported frequently by the description of a single strain. In this study we present 14 strains for these two novel species which increases the phenotypic variability within species. As a consequence, few phenotypic characteristics permits the differentiation of the two close novel species. This situation is frequent in the genus Pseudomonas. For instance, classical subdivision in biotypes that differentiate biovars A and B in the species P. putida are not supported by phylogenetic analyses. This fact is much more complex among species in the P. fluorescens phylogenetic group. As stated by Palleroni in the last version of the Bergey's Manual: "It is quite possible that isolation of more strains of each of the different biovars may result in the future in the proposal of new species with the general properties of $P$. fluorescens, but circumscribed based on genomic differences [24]." Potential phenotypic differential characteristics can be deduced in the comparative genomic analysis as stated below.

\section{Chemotaxonomic analysis: protein profile and fatty acid analysis}

The MALDI-TOF-MS profiles of each strain showed that all strains of the putative novel species were closely related to each other with similarity values higher than $95 \%$, and clustered in the same branch with the type strains of $P$. helmanticensis, $P$. baetica and $P$. koreensis. Other strains with no close relation, including $P$. granadensis or $P$. kribbensis, with no close relation were also outside this cluster. The protein dendrogram is presented in Fig. S2. In this case, the $\mathrm{m} / \mathrm{z}$ protein profiles were not discriminative enough for the identification of these close related species.

Table 3 shows the fatty acids methyl esters analysis results for 4 of the selected isolates $\left(\mathrm{P9}^{\mathrm{T}}, \mathrm{P} 42^{\mathrm{T}}, \mathrm{P} 141\right.$ and CCUG 67011) and two of their closest related type strains $P$. helmanticensis and $P$. baetica, together with $P$. koreensis as representative of the $P$. koreensis SG. The characteristic $C_{16: 0}$ fatty acid of the Pseudomonas genus was present in all strains, together with other major fatty acids $\left(C_{10: 0}\right.$ 3-OH, $\mathrm{C}_{12: 0} 2-\mathrm{OH}$ and $\mathrm{C}_{12: 0} 3-\mathrm{OH}$ ) [24]. P. anatoliensis and P. iridis can be differentiated phenotypically by chemotaxonomy data, using fatty acids methyl ester analysis. While the content of summed feature 3 ranged between $36-38 \%$ for $P$. anatoliensis and $29-30 \%$ for $P$. iridis, the percentage of $C 17: 0$ cyclo was traces$2.16 \%$ for $P$. anatoliensis and $7.48-6.40 \%$ for $P$. iridis. Furthermore, the range of summed feature 8 was $8.54-7.59 \%$ for $P$. anatoliensis and $9.87-10.53 \%$ for $P$. iridis. These characteristics are valuable tools for the differentiation of the proposed two novel species.

\section{General taxonomic genome features}

The $\mathrm{P9}^{\mathrm{T}}$ draft genome was assembled in 18 contigs with an average coverage of $78 \mathrm{X}$. The main characteristics of the whole- 


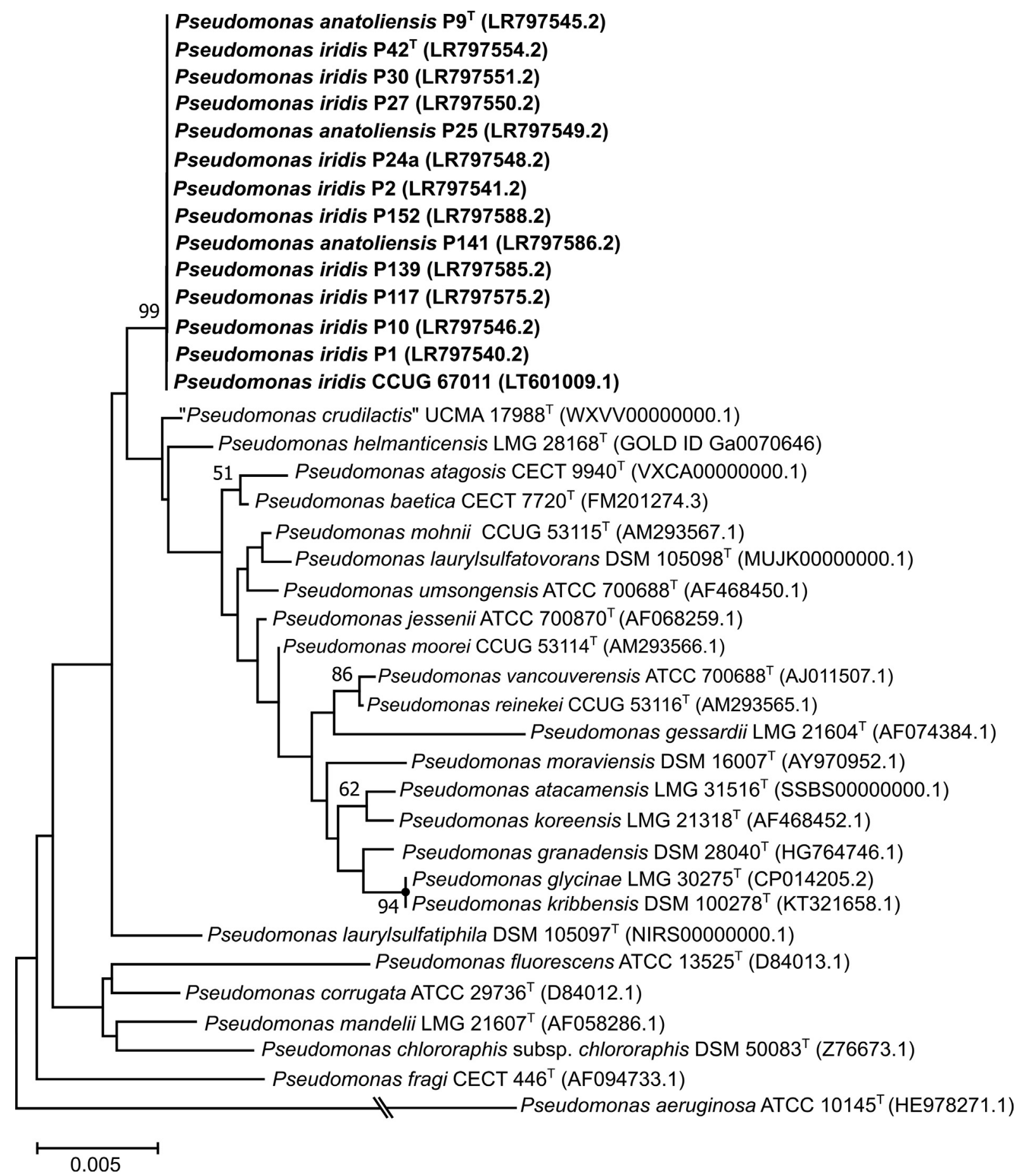

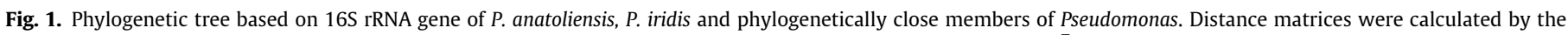

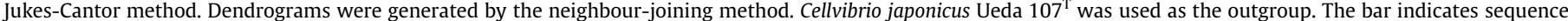

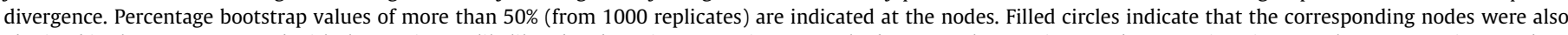

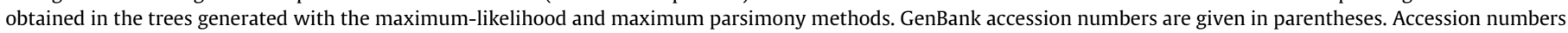
indicated in bold are for sequences determined in this study.

genome sequence of strain $\mathrm{Pg}^{\mathrm{T}}$ are presented in Table S4a. For the P141 genome, 18 contigs with an average 308X coverage were obtained. All genome relatedness values of strain $\mathrm{P}^{\mathrm{T}}$ with its closest relatives in the $P$. koreensis SG calculated with the algorithms ANIb, ANIm and GGDC were clearly below the established cut-off values for each algorithm (ANIb: 95\%, ANIm: 95\% and GGDC: $70 \%$ ), as shown in Table S5. This confirmed that strain $\mathrm{Pg}^{\mathrm{T}}$ represents a novel genomic species in the group. The similarity to the closest relative, $\mathrm{P} 42^{\mathrm{T}}$ was $94.02 \%$ for ANIb, $95.06 \%$ for ANIm and $58.60 \%$ for GGDC. The $\mathrm{P}^{\mathrm{T}}$ and $\mathrm{P} 141$ strains displayed an ANIb percentage of $98.31 \%$, an ANIm percentage of $98.66 \%$ and a GGDC percentage of $87.60 \%$ between them (Table S5). These high similarity values indicate that these two strains belonged to a unique genomic species.

The $\mathrm{P} 42^{\mathrm{T}}$ draft genome was assembled in 18 contigs with an average coverage of $477 \mathrm{X}$. The main characteristics of the whole- 


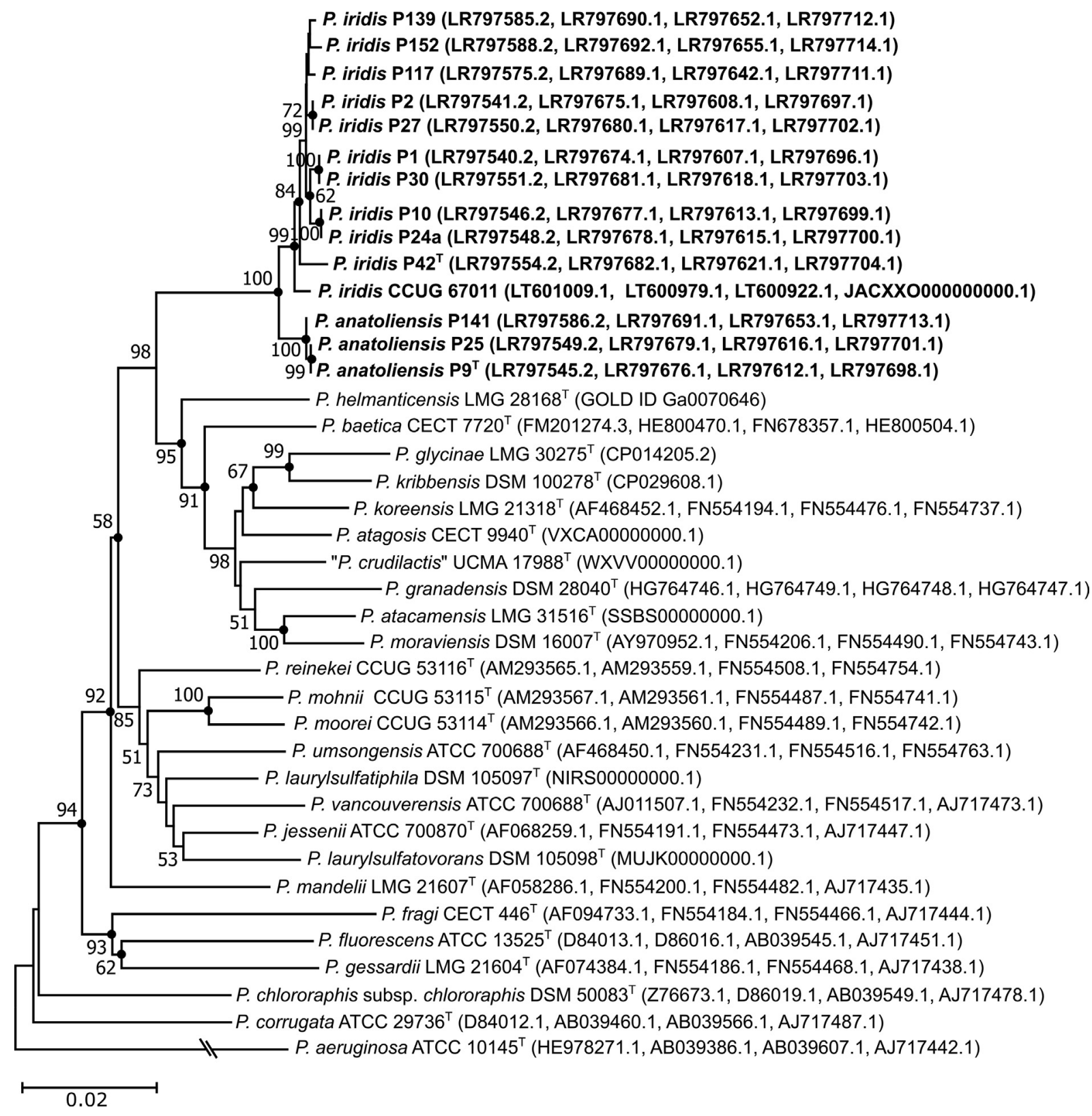

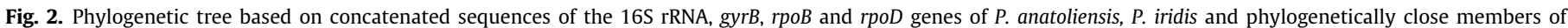

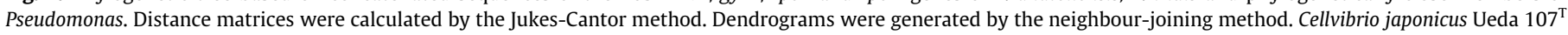

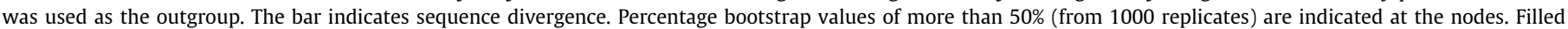

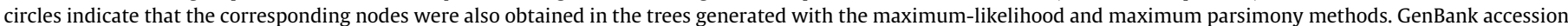

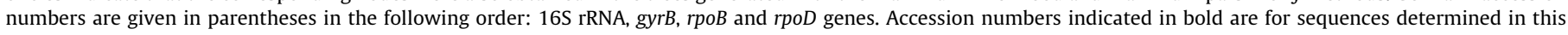
study.

genome sequence of strain $\mathrm{P} 42^{\mathrm{T}}$ are presented in Table S4b. For the CCUG 67011 genome, 46 contigs with an average 560X coverage were obtained. All genome relatedness values of strain $\mathrm{P}^{\mathrm{T}} 2^{\mathrm{T}}$ with its closest relatives in the $P$. koreensis subgroup calculated by using the algorithms ANIb, ANIm and GGDC were clearly below the established cut-off values for each algorithm as shown in Table S5, confirming that strain $\mathrm{P} 42^{\mathrm{T}}$ represents a novel genomic species in the group. The similarity to the closest relative, $P$. anatoliensis $\mathrm{Pg}^{\mathrm{T}}$ was $94.02 \%$ for ANIb, $95.07 \%$ for ANIm and $58.06 \%$ for GGDC. The P42 ${ }^{\mathrm{T}}$ and CCUG 67011 strains showed an ANIb percentages of $96.36 \%$, an ANIm percentages of $97.33 \%$ and a GGDC percentage of $75.60 \%$ (Table S5). These high similarity values indicate that these two strains belonged to a unique genomic species. The genomes of $\mathrm{P}^{\mathrm{T}}, \mathrm{P} 141, \mathrm{P} 42^{\mathrm{T}}$ and CCUG67011 were also com- pared to the genomes of the type strains in the $P$. koreensis subgroup available on the Type (strain) Genome Server (TYGS). The corresponding obtained dendrogram is shown in Fig. S3. The results clearly indicated that the four strains represent a two putative novel species.

Genome comparison between P. anatoliensis and P. iridis strains

In order to identify the proteins that differentiate the two species, a comparative analysis was made between the genomes of the four strains studied. As shown in in the Venn diagram (Fig. 4) both species share 4198 genes, representing between $71 \%$ and $77 \%$ of their respective protein coding genes. The species delineation threshold proposed by Goris and collaborators is $85 \%$ of conserved 


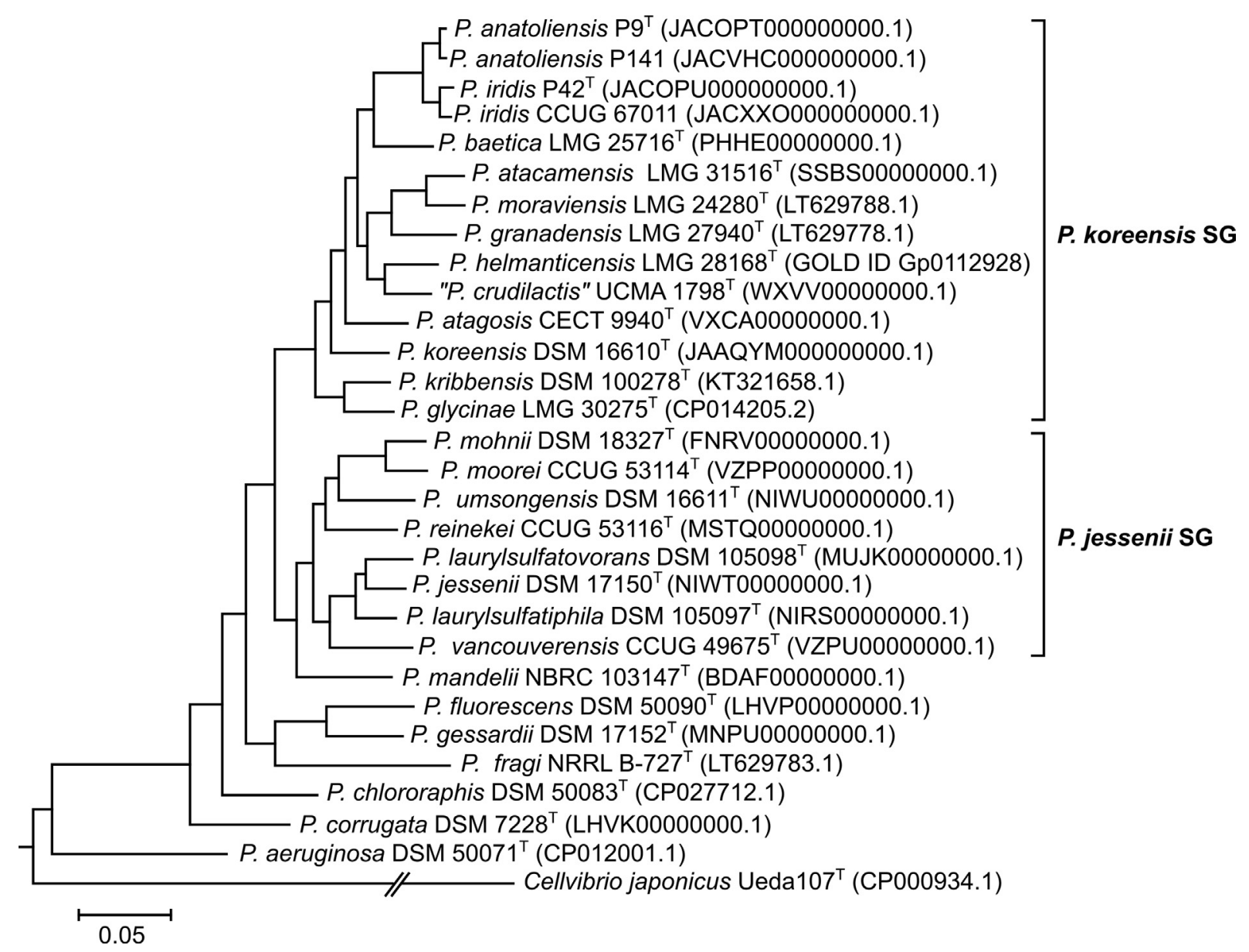

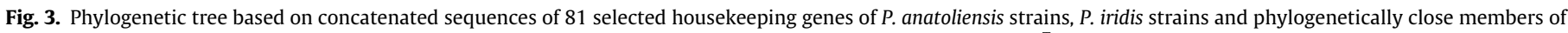

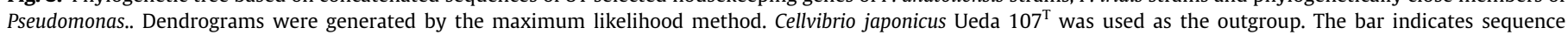
divergence. Percentage bootstrap values of more than 50\% (from 1000 replicates) are indicated at the nodes. GenBank accession numbers are given in parentheses.

proteins [10]. P. anatoliensis strains showed $89 \%$ conserved proteins and $P$. iridis strains showed $86 \%$ conserved proteins. Two-hundred and seventy-six genes were exclusively present in $P$. anatoliensis but not in $P$. iridis.

In the final orthologous table in the M1CROB1AL1Z3R web server 5376 orthologous ORFs were obtained in the analysis of the four genomes under study. ORFs were distributed as follows: 5109 in P. anatoliensis P141; 5105 in P. anatoliensis P9T; 4798 in $P$. iridis P42T and 4716 in $P$. iridis CCUG 67011. The core proteome of the four genomes contained 4314 genes. When $P$. baetica type strain was included in the analysis as outgroup, the core proteome was reduced to 4010 genes, and 5490 orthologous ORFs were found. Fig. 5 shows the phylogenetic tree based on the concatenated nucleotide sequences of the core genes (Fig. 5A) and the dendrogram corresponding to the genes shared by each pair of strains (Fig. 5B). In both figures $P$. anatoliensis and $P$. iridis strains are separated. It is worth to highlight that $P$. anatoliensis strains were closer to $P$. baetica than to $P$. iridis strains in the number of shared ORFs. Fig. 5 demonstrates that $P$. anatoliensis and $P$. baetica not only shared a high number of genes, but also that they have a common ancestor in the analysis of the core genome. The ANIb values of $P$. baetica ranged from 87.59 to $88.2 \%$ with the four strains under study, clearly below the species threshold. As a consequence, $P$. anatoliensis, $P$. baetica and $P$. iridis should be considered three different species.
A function was assigned in the PROKKA analysis to 107 of these proteins, whereas 169 were hypothetical proteins. One-hundred and thirty-one genes were exclusively present in $P$. iridis and not in $P$. anatoliensis. A function was assigned to 58 of these proteins, whereas 73 were hypothetical proteins. Supplemental Table S6 shows the complete list of species-specific genes.

The proteins with function prediction were deeply analyzed to identify potential additional phenotypic traits that could be useful in the differentiation of the two novel species. Exclusive genes coding for two interesting properties were found in $P$. anatoliensis. Both strains of this species possess two toxin/antitoxin systems, one of type I (SmyE/SmyR) and the other of type II (HigBA-2 related to the system RelE/ParE). These systems are considered metabolism regulators that act in response to environmental stress conditions and are involved in biofilms and bacterial virulence [32] (A third interesting differential gene encodes a colicin-like protein containing an S2 type pyocin domain. Colicins mainly act intraspecifically and have an ecological role [26].

Only the HigBA type II toxin/antitoxin system was detected in $P$. iridis strains. This system differs from the HigBA-2 system found in $P$. anatoliensis strains. Three other genes related to environmental factors were predicted in the $P$. iridis strains: (1) Three copies of the universal stress protein UspE, known as involved in protecting the cell against DNA damage. $u s p E$ is induced in the stationary phase and by a variety of stresses causing the growth arrest of cells. 
Table 1

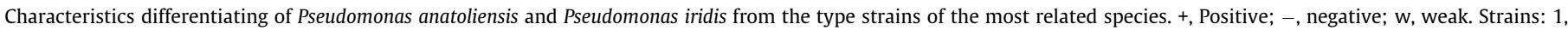

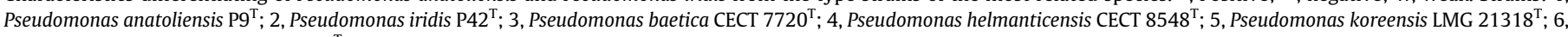
Pseudomonas fluorescens ATCC $13525^{\mathrm{T}}$.

\begin{tabular}{|c|c|c|c|c|c|c|}
\hline Characteristics & 1 & 2 & 3 & 4 & 5 & 6 \\
\hline Temperature (oC) & $4-37$ & $4-37$ & $4-30$ & $4-30$ & $4-30$ & $4-37$ \\
\hline $\mathrm{NaCl}(\%)(\mathrm{w} / \mathrm{v})$ & $0-8$ & $0-9$ & $0-6$ & $0-5$ & $0-6$ & $0-8$ \\
\hline $\mathrm{pH}$ & $7-10$ & $7-9$ & $6-9$ & $5-11$ & $5-9$ & $5-9$ \\
\hline \multicolumn{7}{|l|}{ API 20 NE test: } \\
\hline Presence of arginine dihydrolase & - & + & + & + & + & + \\
\hline Hydrolysis of gelatin & + & + & + & - & - & - \\
\hline \multicolumn{7}{|l|}{ Assimilation of: } \\
\hline Phenylacetate & + & + & - & - & - & - \\
\hline \multicolumn{7}{|l|}{ BIOLOG GENIII test: } \\
\hline \multicolumn{7}{|l|}{ Carbon source utilization assays } \\
\hline D-Sorbitol & - & - & - & - & - & + \\
\hline Tween 40 & + & $\mathrm{w}$ & $\mathrm{w}$ & + & + & + \\
\hline glycyl-L-proline & - & - & - & + & + & + \\
\hline D-Galacturonic Acid & + & + & - & - & - & + \\
\hline Methyl Pyruvate & w & w & + & + & + & w \\
\hline D-Galactonic Acid lactone & - & + & $\mathrm{w}$ & $\mathrm{w}$ & - & w \\
\hline alfa-Hydroxy Butyric Acid & $\mathrm{w}$ & - & - & - & w & + \\
\hline D-Trehalose & + & + & - & - & - & + \\
\hline myo-Inositol & - & - & - & + & - & + \\
\hline D-Glucuronic Acid & + & + & + & - & - & + \\
\hline alfa-Keto-Butyric Acid & w & - & - & - & w & + \\
\hline D-Fucose & - & + & + & + & + & + \\
\hline Glucuronamide & w & + & + & + & + & + \\
\hline Sucrose & - & - & - & - & - & + \\
\hline Mucic acid & + & + & w & + & + & + \\
\hline D-Malic Acid & - & - & w & + & + & + \\
\hline L-Rhamnose & - & - & - & - & - & + \\
\hline D-Serine & - & - & + & + & + & + \\
\hline Bromo-Succinic Acid & - & - & $\mathrm{w}$ & + & + & + \\
\hline Formic Acid & - & - & - & + & + & + \\
\hline \multicolumn{7}{|l|}{ Chemical sensitivity assays } \\
\hline Lithium Chloride & - & + & - & + & + & + \\
\hline Sodium Butyrate & - & - & - & - & w & + \\
\hline Minocycline & + & + & + & - & + & + \\
\hline Sodium Bromate & + & + & + & $\mathrm{W}$ & + & + \\
\hline
\end{tabular}

Most organisms have multiple paralogs of USPs, where the number of copies depends on the organism. (2) A gene coding for an antiseptic resistance protein transporter that belongs to a group of secondary transporters. (3) A gene coding for aquaporin $\mathrm{Z}$ (P42_00343 and CCUG67011_00252). The AqpZ channel is selectively permeable to water, although other functions are not excluded. AqpZ has a role in both the short- and the long-term osmoregulatory response and is required by rapidly growing cells. AqpZ-like proteins seem to be necessary for the virulence expressed by some pathogenic bacteria [4].

Overall, these results indicate that it is of fundamental importance to clarify the taxonomic position of the novel isolates at the species level. P. aeruginosa, P. fluorescens, P. putida and P. syringae are well known species commonly encountered in the aquaculture sector [2]. Today the Pseudomonas genus has become complex and comprises by more than 240 recognized species in the list of prokaryotic names with standing in nomenclature (LPSN DSMZ, https://www.lpsn.dsmz.de). The growing number of species provides a more comprehensive insight into the Pseudomonas genus [15]. Six different species are being proposed as novel species from fish farms in Turkey (manuscript in press [7]). We have demonstrated in this study the presence of strains of the same species of completely different origins, fish or human, and from diverse geographic locations, like Turkey and Sweden. This raises intriguing questions for further genetic, evolutionary and ecological research. This is not the first report of such a case, as a recent publication on $P$. sivasensis, described a similar situation, where strains of different origins were isolated from fish farms, human speci- mens and river water, and $P$. haemolytica originally described as having been isolated from raw milk was also found in fish farms [6]. It is important to determine the prevalence of these strains in this habitat through time (as shown by the different year of isolation in the same aquaculture farm), for a better understanding of any specific role they may play and their correlation with fish and other microorganisms.

\section{Conclusion}

The 16S rRNA nucleotide sequences of the studied strains, showed that they belonged to the genus Pseudomonas. The phenotypic data, MALDI-TOF MS protein profiles and fatty acids methyl esters analysis results revealed that these strains constituted two different groups from the closest type strains of the $P$. koreensis subgroup. Multilocus sequence analyses also located these species in a cluster with their similarity values to the closest type strains lower than the cut-off values established for the species. Finally, the ANIb and GGDC indices confirmed that the representative strains, $\mathrm{P9}{ }^{\mathrm{T}}$ and $\mathrm{P}^{2} 2^{\mathrm{T}}$, showed similarity percentages ranging between $88.20-87.99 \%$ and $37.4-36.70 \%$, respectively, to their closest related known species indicating that they conform not one, but two novel species.

Based on all the phenotypic, chemotaxonomic, and phylogenetic and genomic results obtained in the present study, we conclude the strains $\mathrm{P}^{\mathrm{T}}$ and $\mathrm{P} 25$ and P141, represent a novel species for which the name of Pseudomonas anatoliensis sp. nov. is pro- 
Table 2A

Description of Pseudomonas anatoliensis sp. nov.

\begin{tabular}{|c|c|}
\hline Species name & Pseudomonas anatoliensis \\
\hline Genus name & Pseudomonas \\
\hline Specific epithet & Anatoliensis \\
\hline Species status & sp. nov. \\
\hline Species etymology & a.na.to.li.en'sis. L. fem. adj. anatoliensis, from Anatolia where the strain was isolated \\
\hline Designation of the type strain & P9 \\
\hline Strain collection numbers & CECT 30172, CCUG 74755 \\
\hline 16S rRNA gene accession number & LR797545 \\
\hline Alternative housekeeping genes & gyrB gene [LR797676], rpoD gene [LR797698] and $r p o B$ gene [LR797612] \\
\hline Genome accession number & JACOPT000000000 \\
\hline Genome status & Draft \\
\hline Genome size (pb) & $6,453,902$ \\
\hline GC $\mathrm{mol} \%$ & 58,7 \\
\hline Country of origin & Turkey \\
\hline Region of origin & Central Anatolia \\
\hline Other & Kayseri \\
\hline Date of isolation & December 2013 \\
\hline Source of isolation & Oncorhynchus mykiss (abdominal cavity) \\
\hline Sampling date & December 2013 \\
\hline Geographic location & Kayseri \\
\hline Latitude & $38^{\circ} 57^{\prime} 57.4^{\prime \prime} \mathrm{N}$ \\
\hline Longitude & $36^{\circ} 40^{\prime} 07.2^{\prime \prime} \mathrm{E}$ \\
\hline Depth & 0 \\
\hline Altitude (alti) & 0 \\
\hline Number of strains in study & 3 \\
\hline Source of isolation of non-type strains & Oncorhynchus mykiss (abdominal cavity) \\
\hline $\begin{array}{l}\text { Growth medium, incubation conditions used } \\
\text { for standard cultivation }\end{array}$ & Luria-Bertani medium (LB) at $30^{\circ} \mathrm{C}$ \\
\hline Gram stain & NEGATIVE \\
\hline Cell shape & rod \\
\hline Cell size (length or diameter) & 3.7-3.1 $\mu \mathrm{m}$ long and $0.9-1.1 \mu \mathrm{m}$ wide \\
\hline Motility & Motile \\
\hline If motile & flagellar \\
\hline If flagellated & one polar flagellum \\
\hline Sporulation (resting cells) & none \\
\hline Colony morphology & $\begin{array}{l}\text { Round, flat, opaque and beige coloured, with regular margins and translucent margins (3-6 mm in diameter) and } \\
\text { approximately } 3-6 \mathrm{~mm} \text { in diameter after growth for } 2 \text { days at } 30^{\circ} \mathrm{C} \text { on LB plates. }\end{array}$ \\
\hline Temperature range & $4-37$ \\
\hline Lowest temperature for growth & 4 \\
\hline Higuest temperature for growth & 37 \\
\hline Temperature optimum & 30 \\
\hline Lowest pH for growth & 7 \\
\hline Highest $\mathrm{pH}$ for growth & 10 \\
\hline Lowest $\mathrm{NaCl}$ concentration for growth & 0 \\
\hline Highest $\mathrm{NaCl}$ concentration for growth & 8 \\
\hline Salinity category & moderate halophile (optimum $7-15 \% \mathrm{NaCl}$ ) \\
\hline Positive tests with BIOLOG & $\begin{array}{l}\text { The strains have the ability to oxidize: alfa-D-glucose, D-mannose, D-galacturonic acid, gamma-amino-butyric acid, } \\
\text { D-fructose, L-alanine, D-galactose, L-arginine, D-gluconic acid, L-lactic acid, beta-hydroxy-D,L-butyric acid, glycogen, } \\
\text { L-aspartic acid, D-glucuronic acid, citric acid, } \mathrm{N} \text {-acetyl-D-glucosamine, L-glutamic acid, alfa-keto glutaric acid, L- } \\
\text { histidine, mucic acid, propionic acid, L-pyroglutamic acid, quinic acid, L-malic acid, acetic acid, inosine, L-serine and } \\
\text { D-saccharic acid, Strains were able to grow at } 1 \% \mathrm{NaCl}, 4 \% \mathrm{NaCl}, 1 \% \text { sodium lactate, troleandomycin, lincomycin, } \\
\text { vancomycin, nalidixic acid, aztreonam, } \mathrm{pH} 5, \mathrm{pH} 6 \text {, fusidic acid, rifamycin } \mathrm{SV} \text {, guanidine } \mathrm{HCl} \text {, tetrazolium violet, D- } \\
\text { serine, minocycline, nioproof } 4 \text {, tetrazolium blue, potassium tellurite and sodium bromate }\end{array}$ \\
\hline Negative tests with BIOLOG & $\begin{array}{l}\text { The strains were unable to oxidize: D-raffinose, D-sorbitol, gelatin, pectin, p-hydroxy-phenylacetic acid, dextrin, alfa- } \\
\text { D-lactose, glycyl-L-proline, D-maltose, D-melibiose, D-lactic acid methyl ester, beta-methyl-D-glucoside, myo- } \\
\text { inositol, D-cellobiose, D-salicin, 3-methyl glucose, gentiobiose, D-glucose-6-PO4, acetoacetic acid, sucrose, N-acetyl- } \\
\text { beta-D-mannosamine, L-fucose, D-fructose-6-PO4, D-malic acid, turanose, N-acetyl-D-galactosamine, L-rhamnose, D- } \\
\text { aspartic acid, stachyose, N-acetyl-neuraminic acid, D-serine, formic acid. Strains were unable to grow at lithium } \\
\text { chloride and sodium butyrate }\end{array}$ \\
\hline Variable tests with BIOLOG & $\begin{array}{l}\text { Tween } 40 \text {, D-mannitol, methyl pyruvate, D-arabitol, D-galactonic acid lactone, D-trehalose, D-fucose, glucuronamide } \\
\text { and bromo-succinic acid }\end{array}$ \\
\hline Positive tests with API & $\begin{array}{l}\text { hydrolysis of gelatin and the assimilation of glucose, arabinose, mannose, mannitol, N-acetyl-D-glucosamine, } \\
\text { gluconate, caprate, malate and citrate }\end{array}$ \\
\hline Negative tests with API (APIN) & $\begin{array}{l}\text { Reduction of nitrate to nitrite and nitrite to } \mathrm{N}_{2} \text {, indole production, glucose fermentation, the urease, hydrolysis of } \\
\text { aesculin, the beta-galactosidase and the assimilation of maltose and adipate }\end{array}$ \\
\hline Variable tests with API (APIV) & presence of arginine dihydrolase and assimilation of phenylacetate \\
\hline Commercial kits used & BIOLOG GENIII, API 20NE \\
\hline Energy metabolism & chemoorganotroph \\
\hline Oxidase & positive \\
\hline Catalase & positive \\
\hline Negative tests & Pigment on King A agar \\
\hline Major fatty acids & $\begin{array}{l}\text { Sum In Feature } 3\left(C_{16: 1} \omega 7 c \text { and/or } C_{16: 1} \omega 6 c, 38.64-36.81 \%\right), C_{16: 0}(36.91-35.16 \%), \text { Sum In Feature } 8\left(C_{18: 1} \omega 6 c \text { and } / \text { or }\right. \\
\left.C_{18: 1} \omega 7 c, 8.54-7.59 \%\right), C_{12: 0} 20 H(5.20-5.06 \%), C_{10: 0} 30 H(4.43-3.69 \%), C_{12: 0} 30 H(4.21-4.16 \%) \text { and } C_{12: 0}(2.16-2.08 \%)\end{array}$ \\
\hline Biosafety level & 1 \\
\hline Habitat & fish farm (http://purl.obolibrary.org/obo/ENVO_00000294) \\
\hline Biotic relationship & free-living \\
\hline Known pathogenicity & None \\
\hline
\end{tabular}


Table 2B

Description of Pseudomonas iridis sp. nov.

\begin{tabular}{|c|c|}
\hline Species name & Pseudomonas iris \\
\hline Genus name & Pseudomonas \\
\hline Specific epithet & iridis \\
\hline Species status & sp. nov. \\
\hline Species etymology & i'ri.dis. L. gen. n. iridis, of Iris, the Greek goddess of the rainbow \\
\hline Designation of the type strain & P42 \\
\hline Strain collection numbers & CECT 30174 , CCUG 74870 \\
\hline 16S rRNA gene accession number & LR797554 \\
\hline Alternative housekeeping genes & gyrB gene [LR797682], rpoD gene [LR797704] and rpoB gene [LR797621] \\
\hline Genome accession number & JACOPUO00000000 \\
\hline Genome status & Draft \\
\hline Genome size $\mathrm{pb}$ & $6,141,407$ \\
\hline GC $\mathrm{mol} \%$ & 58,8 \\
\hline Country of origin & Turkey \\
\hline Region of origin & Central Anatolia \\
\hline Other & Kayseri \\
\hline Date of isolation & March 2014 \\
\hline Source of isolation & Oncorhynchus mykiss (abdominal cavity) \\
\hline Sampling date & March 2014 \\
\hline Geographic location & Kayseri \\
\hline Latitude & $38^{\circ} 57^{\prime} 57.4^{\prime \prime} \mathrm{N}$ \\
\hline Longitude & $36^{\circ} 40^{\prime} 07.2^{\prime \prime} \mathrm{E}$ \\
\hline Depth & 0 \\
\hline Altitude (alti) & 0 \\
\hline Number of strains in study & 11 \\
\hline Source of isolation of non-type strains & Oncorhynchus mykiss (abdominal cavity) \\
\hline $\begin{array}{l}\text { Growth medium, incubation conditions used } \\
\text { for standard cultivation }\end{array}$ & Luria-Bertani medium (LB) at $30^{\circ} \mathrm{C}$ \\
\hline Gram stain & NEGATIVE \\
\hline Cell shape & Rod \\
\hline Cell size (length or diameter) & $0.8-1.8 \mu \mathrm{m}$ long and $0.4-0.7 \mu \mathrm{m}$ wide \\
\hline Motility & Motile \\
\hline If motile & flagellar \\
\hline If flagellated & one polar flagellum \\
\hline Sporulation (resting cells) & none \\
\hline Colony morphology & $\begin{array}{l}\text { Round, flat, opaque and beige coloured, with regular margins and translucent margins (3-6 mm in diameter) and } \\
\text { approximately 3-6 mm in diameter after growth for } 2 \text { days at } 30^{\circ} \mathrm{C} \text { on LB plates. }\end{array}$ \\
\hline Temperature range & $4-37$ \\
\hline Lowest temperature for growth & 4 \\
\hline Higuest temperature for growth & 37 \\
\hline Temperature optimum & 30 \\
\hline Lowest $\mathrm{pH}$ for growth & 7 \\
\hline Highest $\mathrm{pH}$ for growth & 9 \\
\hline Lowest $\mathrm{NaCl}$ concentration for growth & 0 \\
\hline Highest $\mathrm{NaCl}$ concentration for growth & 8 \\
\hline Salinity category & moderate halophile (optimum $7-15 \% \mathrm{NaCl}$ ) \\
\hline Positive tests with BIOLOG & $\begin{array}{l}\text { The strains have the ability to oxidize: alfa-D-glucose, D-mannose, D-mannitol, D-galacturonic acid, gamma-amino- } \\
\text { butyric acid, D-fructose, D-arabitol, L-alanine, D-falactose, L-arginine, D-gluconic acid, L-lactic acid, beta-hydroxy-D, } \\
\text { L-butyric acid, glycogen, L-aspartic acid, D-glucuronic acid, citric acid, L-glutamic acid, glucuronamide, alfa-keto- } \\
\text { glutaric acid, L-histidine, mucic acid, propionic acid, L-pyroglutamic acid, quinic acid, L-malic acid, acetic acid, } \\
\text { inosine, L-serine, D-saccharic acid. Strains were unable to grow at } 1 \% \mathrm{NaCl}, 4 \% \mathrm{NaCl}, \mathrm{pH} 5, \mathrm{pH} 6,1 \% \text { sodium lactate, } \\
\text { troleandomycin, lincomycin, vancomycin, nalidixic acid, aztreonam, fusidic acid, rifamycin SV, guanidine } \mathrm{HCl} \text {, } \\
\text { tetrazolium violet, D-serine, minocycline, Nioproof } 4 \text {, tetrazolium blue, potassium tellurite, sodium bromate }\end{array}$ \\
\hline Negative tests with BIOLOG & $\begin{array}{l}\text { The strains were unable to oxidize: D-raffinose, D-sorbitol, gelatin, pectin, p-hydroxy-phenylacetic acid, dextrin, alfa- } \\
\text { D-lactose, glycyl-L-proline, D-maltose, D-melibiose, D-lactic acid methyl ester, alfa-hydroxy butyric acid, beta- } \\
\text { methyl-D-glucoside, myo-inositol, D-cellobiose, D-salicin, 3-methyl glucose, alfa-keto-butyric acid, gentiobiose, D- } \\
\text { glucose-6-PO4, acetoacetic acid, sucrose, N-acetyl-beta-D-mannosamine, L-fucose, D-fructose-6-PO4, turanose, N- } \\
\text { acetyl-D-galactosamine, L-rhamnose, D-aspartic acid, stachyose, N-acetyl-neuraminic acid }\end{array}$ \\
\hline Variable tests with BIOLOG & D-malic acid, D-serine, bromo-succinic acid, formic acid and sodium butyrate \\
\hline Positive tests with API & The assimilation of glucose, arabinose, mannose, mannitol, gluconate, caprate, malate and citrate \\
\hline Negative tests with API (APIN) & $\begin{array}{l}\text { Reduction of nitrate to nitrite and nitrite to } \mathrm{N}_{2} \text {, glucose fermentation, the urease, the beta-galactosidase and the } \\
\text { assimilation of maltose and adipate }\end{array}$ \\
\hline Variable tests with API (APIV) & $\begin{array}{l}\text { Indole production, presence of arginine dihydrolase, hydrolysis of aesculin and gelatin, N-acetyl-D-glucosamine and } \\
\text { phenylacetate }\end{array}$ \\
\hline Commercial kits used? & BIOLOG GENIII, API 20NE \\
\hline Energy metabolism & Chemoorganotroph \\
\hline Oxidase & Positive \\
\hline Catalase & positive \\
\hline Negative tests & Pigment on King A agar \\
\hline Major fatty acids & $\begin{array}{l}C_{16: 0}(36.09-35.97 \%), \text { Sum In Feature } 3\left(C_{16: 1} \omega 7 c \text { and/or } C_{16: 1} \omega 6 c, 30.66-29.86 \%\right), \text { Sum In Feature } 8\left(C_{18: 1} \omega 6 c \text { and/or }\right. \\
\left.C_{18: 1} \omega 7 c, 10.53-9.87 \%\right), C_{17: 0} \text { cyclo }(7.48-6.40 \%), C_{12: 0} 20 H(5.36-4.85 \%), C_{12: 0} 30 H(4.28-4.20 \%), C_{10: 0} 30 H(4.16- \\
3.58 \%) \text { and } C_{12: 0}(2.26-1.70 \%)\end{array}$ \\
\hline Biosafety level & 1 \\
\hline Habitat & fish farm (http://purl.obolibrary.org/obo/ENVO_00000294) \\
\hline Biotic relationship & free-living \\
\hline Known pathogenicity & none \\
\hline
\end{tabular}


Table 3

Cellular fatty composition (\%) derived from FAME analysis of Pseudomonas anatoliensis, Pseudomonas iridis and the type strains of closely related Pseudomonas species.

\begin{tabular}{|c|c|c|c|c|c|c|c|}
\hline Fatty acids (\%) & 1 & 2 & 3 & 4 & 5 & 6 & 7 \\
\hline $\mathrm{C}_{10: 0} 3 \mathrm{OH}$ & 4.43 & 3.69 & 4.16 & 3.58 & 3.63 & 2.4 & 4.3 \\
\hline $\mathrm{C}_{12: 0}$ & 2.16 & 2.08 & 1.70 & 2.26 & 2.09 & 2.0 & 3.8 \\
\hline $\mathrm{C}_{12: 0} 2 \mathrm{OH}$ & 5.06 & 5.20 & 5.36 & 4.85 & 4.97 & 4.9 & 6.4 \\
\hline $\mathrm{C}_{12: 0} 3 \mathrm{OH}$ & 4.16 & 4.21 & 4.28 & 4.20 & 3.77 & 2.9 & 4.9 \\
\hline $\mathrm{C}_{14: 0}$ & TR & TR & TR & TR & TR & TR & TR \\
\hline Sum In Feature 3 & 38.64 & 36.81 & 29.86 & 30.66 & 34.70 & 32.9 & 23.8 \\
\hline $\mathrm{C}_{16: 0}$ & 35.16 & 36.91 & 35.97 & 36.09 & 37.50 & 31.9 & 27.9 \\
\hline $\mathrm{C}_{17: 0}$ cyclo & TR & 2.16 & 7.48 & 6.40 & 3.42 & 5.1 & 16.0 \\
\hline Sum In Feature 8 & 8.54 & 7.59 & 9.87 & 10.53 & 8.62 & 15.6 & 11.4 \\
\hline$C_{18: 0}$ & $\mathrm{TR}$ & $\mathrm{TR}$ & TR & $\mathrm{TR}$ & TR & TR & - \\
\hline
\end{tabular}

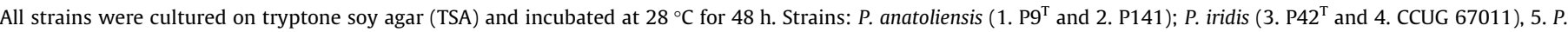

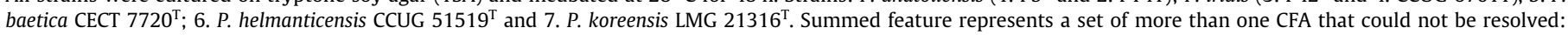
summed feature 3 contained $C_{16: 1} \omega 7 c$ and/or $C_{16: 1} \omega 6 c$ and summed feature 8 contained $C_{18: 1} \omega 6 c$ and/or $C_{18: 1} \omega 7 c$; - , not detectable; TR, trace amount (<1\%).

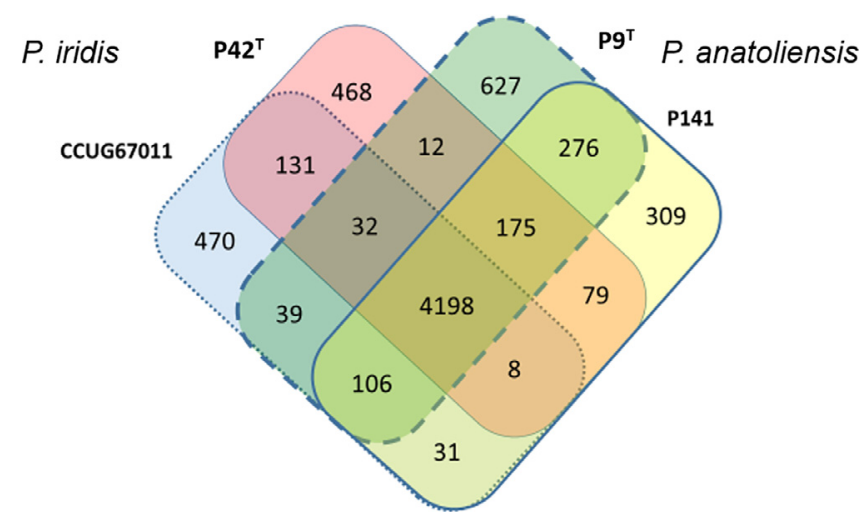

Fig. 4. Venn diagram of the common and differential genes shared by P. anatoliensis and $P$. iridis strains.

posed, with $\mathrm{P}^{\mathrm{T}}$ as a type strain $\left(=\right.$ CCUG $74755^{\mathrm{T}}=$ and CECT $\left.3172^{\mathrm{T}}\right)$. The isolates P1, P2. P10, P27, P30, P24a, P42 ${ }^{\mathrm{T}}, \mathrm{P} 117, \mathrm{P} 139, \mathrm{P} 141$, P152 and CCUG 67011 represent another novel species for which the name Pseudomonas iridis sp. nov. is proposed, with $\mathrm{P} 42^{\mathrm{T}}$ as a type strain (=CCUG $74870^{\mathrm{T}}=$ and CECT $3174^{\mathrm{T}}$ ). These species are predominantly found in aquatic habitats.
Nucleotide sequence accession numbers: The GenBank/EMBL/ DDBJ accession numbers of the nucleotide sequences reported in this study are as follows: LR797545, LR797549 and LR797586 (strains Pseudomonas anatoliensis $\mathrm{P}^{\mathrm{T}}, \mathrm{P} 25$ and P141) and LR797540-LR797541, LR797546, LR797548, LR797550-LR797551, LR797554-LR797575, LR797585 and LR797588 (strains Pseudomonas iridis P1, P2, P10, P24a, P27, P30, P42 ${ }^{\mathrm{T}}, \mathrm{P} 117, \mathrm{P} 139$ and P152) for the 16S rRNA gene; LR797676, LR797679 and LR797691 (strains Pseudomonas anatoliensis P9 ${ }^{\mathrm{T}}, \mathrm{P} 25$ and P141) and LR797674-LR797675, LR797677- LR797678, LR797680LR797682, LR797689-LR797690 and LR797692 (strains Pseudomonas iridis P1, P2, P10, P24a, P27, P30, P42 ${ }^{\mathrm{T}}, \mathrm{P} 117, \mathrm{P} 139$ and P152) for the gyrB gene; LR797698, LR797701 and LR797713 (strains Pseudomonas anatoliensis $\mathrm{P}^{\mathrm{T}}, \mathrm{P} 25$ and P141) and LR797696-LR797697, LR797699-LR797700, LR797702-LR797704, LR797711-LR797712 and LR797714 (strains Pseudomonas iridis P1, P2, P10, P24a, P27, P30, P42 ${ }^{\mathrm{T}}$, P117, P139 and P152) for the rpoB gene; LR797612, LR797616 and LR797653 (strains Pseudomonas anatoliensis $\mathrm{P9}^{\mathrm{T}}, \mathrm{P} 25$ and P141) and LR797607-LR797608, LR797613, LR797615, LR797617-LR797618, LR797621, LR797642, LR797652 and LR797655 strains Pseudomonas iridis P1, P2, P10, P24a, P27, P30, P42 ${ }^{\mathrm{T}}, \mathrm{P} 117, \mathrm{P} 139$ and P152) for the $r p o D$ gene.

The accession numbers for the genome sequences of strains $P 9^{\mathrm{T}}$ and $\mathrm{P}^{2} 2^{\mathrm{T}}$, P141 and CCUG67011 are: JACOPT000000000,
A)

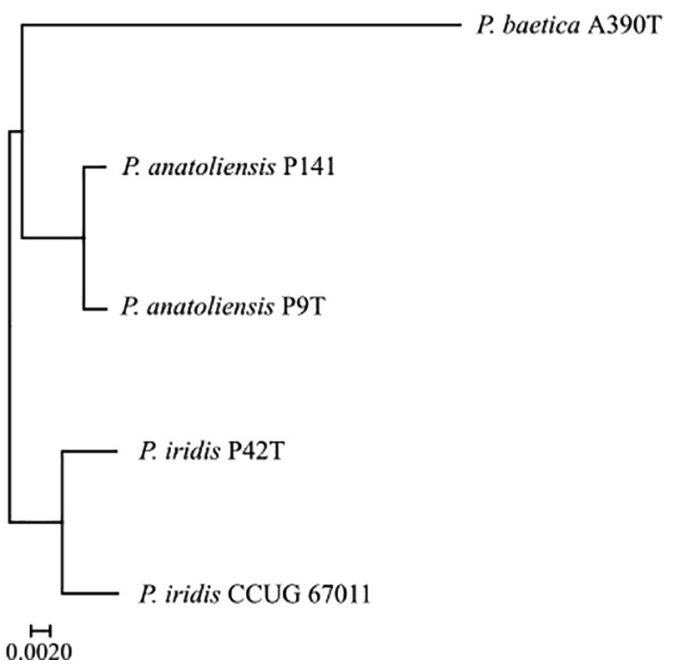

B)

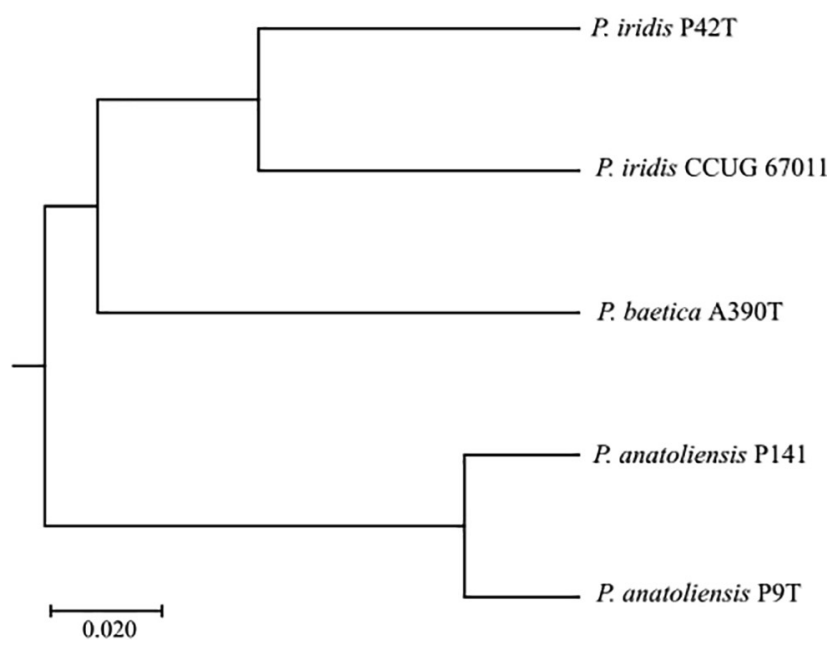

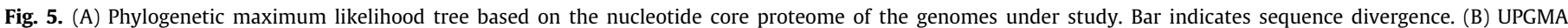
dendrogram of the orthologous protein coding genes among the strains under study. Scale bar indicates distance measurement. 
JACOPU000000000, JACVHC000000000, and JACXX0000000000 respectively. The version described in this paper is the first version.

\section{Acknowledgements}

This research was supported by the Scientific and Technological Research Council of Turkey (TUBITAK) [No: 1180420]. We are thankful to Bursa Uludag University for providing additional support. This research was approved by the institutional Local Ethics Commission (report 2012-14-04).

The authors acknowledge the CCUG (Culture Collection of the University of Gothenburg, Sweden) for providing the strain CCUG 67011. The authors would also like to acknowledge Prof. Dr. Bernhard Schink (University of Konstanz, Germany) for this advice in compounding Latin specific epithets.

\section{Appendix A. Supplementary data}

Supplementary data to this article can be found online at https://doi.org/10.1016/j.syapm.2021.126198.

\section{References}

Alanjary, M., Steinke, K., Ziemert, N., ]. AutoMLST: an automated web server for generating multi-locus species trees highlighting natural product potential. Nucleic Acids Res. 47 (W1), W276-W282.

Austin, B., Austin, D.A., ]. Pseudomonads. Bacterial Fish Pathogens. Springer International Publishing, pp. 475-498.

Avram, O., Rapaport, D., Portuguez, S., Pupko, T., ]. M1CROB1AL1Z3R-a user-friendly web server for the analysis of large-scale microbial genomics data. Nucleic Acids Res. 47, 88-92. https://doi.org/10.1093Inarlgkz423.

Calamita, G., ]. The Escherichia coli aquaporin-Z water channel. Mol. Microbiol. 37, 254-262. https://doi.org/10.1046/j.1365-2958.2000.02016.x.

Contreras-Moreira, B., Vinuesa, P., ]. GET_HOMOLOGUES, a versatile software package for scalable and robust microbial pangenome analysis. Appl. Environ. Microbiol. 79, 7696-7701. https://doi.org/10.1128/AEM.02411-13.

Duman, M., Mulet, M., Saticioglu, I.B., Altun, S., Gomila, M., Lalucat, J., García-Valdés, E., ]. Pseudomonas sivasensis sp. nov. isolated from farm fisheries in Turkey. Syst. Appl. Microbiol. 43, (4) 126103.

Duman, M., Mulet, M., Altun, S., Saticioglu, I.B., Ozdemir, B., Ajmia, N., Lalucat, J., García-Valdés, E., ]. The diversity of Pseudomonas species isolated from fish farms in Turkey. Aquaculture (in press). https://doi.org/10.1016/j. aquaculture.2021.736369.

Farris, J.S., ]. Estimating phylogenetic trees from distance matrices. Am. Nat. 106 (951), 645-668.

Felsenstein, J., ]. Evolutionary trees from DNA sequences: a maximum likelihood approach. J. Mol. Evol. 17, 368-376.

Goris, J., Konstantinidis, K.T., Klappenbach, J.A., Coenye, T., Vandamme, P., Tiedje, J. M., 0]. DNA-DNA hybridization values and their relationship to whole-genome sequence similarities. Int. J. Syst. Evol. Microbiol. 57, 81-91. https://doi.org/ 10.1099/ijs.0.64483-0.
Hammer, Ø., Harper, D.A.T., Ryan, P.D., 1]. PAST: Paleontological statistics software package for education and data analysis. Palaeontologia Electronica 4 (1), 9. http://palaeo-electronica.org/2001_1/past/issue1_01.htm.

Hofmann, K., Huptas, C., Doll, E.V., Scherer, S., Wenning, M., 2]. Pseudomonas haemolytica sp. nov., isolated from raw milk and skimmed milk concentrate. Int. J. Syst. Evol. Microbiol. 70 (4), 2339-2347.

Jukes, T., Cantor, C., 3]. Evolution of protein molecules. In: Munro, H.N. (Ed.), Mammalian Protein, Metabolism. Academic Press, New York, pp. 21-132.

Lalucat, J., 4]. Analysis of refractile (R) bodies. In: Mayer, E. (Ed.), Methods in microbiology-electron microscopy in microbiology. Academic Press, London, pp. 79-90.

Lalucat, J., Mulet, M., Gomila, M., García-Valdés, E., 5]. Genomics in bacterial taxonomy: impact on the genus Pseudomonas. Genes 11, 139.

Lamichhane, J.R., Varvaro, L., 6]. A new medium for the detection of fluorescent pigment production by pseudomonads. Plant. Pathol. 62, 624-632.

Meier-Kolthoff, J.P., Auch, A.F., Klenk, H.P., Göker, M., 7]. Genome sequence-based species delimitation with confidence intervals and improved distance functions. BMC Bioinf. 14, 60.

Meier-Kolthoff, J.P., Göker, M., 8]. TYGS is an automated high-throughput platform for state-of-the-art genome-based taxonomy. Nat. Commun. 10, 2182.

Mulet, M., Gomila, M., Ramírez, A., Cardew, S., Moore, E.R., Lalucat, J., García-Valdés, E., 9]. Uncommonly isolated clinical Pseudomonas: identification and phylogenetic assignation. Eur. J. Clin. Microbiol. Infect. Dis. 36, 351-359.

Mulet, M., Lalucat, J., García-Valdés, E., 0]. DNA sequence-based analysis of the Pseudomonas species. Environ. Microbiol. 12, 1513-1530.

Nei, M., Kumar, S., 1]. Molecular Evolution and Phylogenetics. Oxford University Press, New York.

Oh, W.T., Jun, J.W., Giri, S.S., Yun, S., Kim, H.J., Kim, S.G., Kim, S.W., Kang, J.W., Han, S. J., Kwon, J., Kim, J.H., Smits, T.H.M., Park, S.C., 2]. Pseudomonas tructae sp. Nov., novel species isolated from rainbow trout kidney. Int. J. Syst. Evol. Microbiol. 69, 3851-3856.

OIE (World Organization for Animal Health), Fish Diseases Commission, 3]. Diagnostic Manual for Aquatic Animal Diseases. Office International Des Epizooties, Paris, France, pp. 4-16.

Palleroni, N.J., 4]. Genus I. Pseudomonas Migula 1984, 237AL. In: Krieg, N.R., Holt, J. G. (Eds.), Bergey's Manual of Systematic Bacteriology. Williams \&Wilkins Baltimore, pp. 141-199.

Richter, M., Rosselló-Mora, R., 5]. Shifting the genomic gold standard for the prokaryotic species definition. PNAS 106 (45), 19126-19131.

Riley, M.A., Gordon, D.M., 6]. The ecological role of bacteriocins in bacterial competition. Trends Microbiol 7, 129-133. https://doi.org/10.1016/s0966842x (99) 01459-6.

Saitou, N., Nei, M., 7]. The neighbor-joining method. A new method for reconstructing phylogenetic trees. Biol. and Evol. 4, 406-425.

Sánchez, D., Matthijs, S., Gomila, M., Tricot, C., Mulet, M., García-Valdés, E., Lalucat, J., 8]. rpoD gene pyrosequencing for the assessment of Pseudomonas diversity in a water sample from the Woluwe River. Appl. Environ. Microbiol. 80, 47384744.

Tamura, K., Peterson, D., Peterson, N., Stecher, G., Nei, M., Kumar, S., 9]. MEGA5: molecular evolutionary genetics analysis using maximum likelihood, evolutionary distance, and maximum parsimony methods. Mol. Biol. Evol. 28 (10), 2731-2739.

Seemann, T., 0]. Prokka: rapid prokaryotic genome annotation. Bioinformatics 30 2068-2069. https://doi.org/10.1093/bioinformatics/btu153.

Tatusova, T., DiCuccio, M., Badretdin, A., Chetvernin, V., Nawrocki, E.P., Zaslavsky, L. Ostell, J., 1]. NCBI prokaryotic genome annotation pipeline. Nucleic Acids Res. 44 (14), 6614-6624.

Wen, Y., Behiels, E., Devreese, B., 2]. Toxin-Antitoxin systems: their role in persistence, biofilm formation, and pathogenicity. Pathogens Dis. 70 (3), 240249. https://doi.org/10.1111/2049-632X.12145. 